\title{
IL17A wt Allele
}

National Cancer Institute

\section{Source}

National Cancer Institute. IL17A wt Allele. NCI Thesaurus. Code C49796.

Human IL17A wild-type allele is located within 6p12 and is approximately $4 \mathrm{~kb}$ in length.

This allele, which encodes interleukin-17A protein, plays a role in pro-inflammatory

cytokine regulation. 